\title{
Knowledge and critical thinking skills increase clinical reasoning ability in urogenital disorders: a Universitas Sriwijaya Medical Faculty experience
}

\author{
Irfannuddin \\ Education Development and Evaluation Unit, Sriwijaya University, Medical Faculty
}

\begin{abstract}
Abstrak
Tujuan Kemampuan penalaran klinik adalah salah satu kompetensi utama yang harus dimiliki oleh lulusan dokter sehingga perlu dilatih sejak mahasiswa. Akan tetapi, pembuktian kuantitatif tentang faktor-faktor yang mempengaruhi kemampuan penalaran klinik mahasiswa masih sangat sedikit. Penelitian ini bertujuan untuk menentukan pengaruh pengetahuan dan faktor lainnya terhadap kemampuan penalaran klinik mahasiswa sebagai bahan acuan dalam menentukan metode pembelajaran penalaran klinik.

Metode Penelitian potong lintang dilakukan terhadap mahasiswa Fakultas Kedokteran Universitas Sriwijaya program KBK semester IV. Data yang diambil adalah tentang kemampuan penalaran klinik dengan faktor risikonya pada kasus sistem urogenital karena saat data diambil pada April 2008, mahasiswa baru menyelesaikan pembelajaran blok urogenital. Kemampuan penalaran klinik dinilai dengan tes script concordance dan faktor risiko dinilai berdasarkan hasil evaluasi formatif, sumatif blok dan karakterisitk mahasiswa. Analisis data dilakukan dengan metode regresi Cox.

Hasil Hasil penelitian terhadap 132 mahasiswa menunjukkan persentase kemampuan penalaran klinik yang rendah sebesar 38,6\%. Mahasiswa yang mempunyai pengetahuan yang rendah dibandingkan dengan yang tinggi mempunyai $63 \%$ lebih tinggi risiko mengalami penalaran klinik yang rendah ( $R R$ suaian $=1,63 ; 95 \%$ interval kepercayaan $(C I)=$ 1,10-2,42). Dibanding dengan kelompok mahasiswa yang terampil berpikir kritis, mahasiswa yang tidak terampil berpikir kritis lebih berisiko dua kali lebih mempunyai penalaran klinikyang rendah ( $R R$ suaian $=2,30 ; 95 \%$ interval kepercayaan $(\mathrm{CI})=1,55-3,41)$.
\end{abstract}

Kesimpulan Dari penelitian ini dapat disimpulkan bahwa mahasiswa yang tidak terampil berpikir kritis atau memiliki pengetahuan yang rendah memiliki kemampuan penalaran klinik yang rendah. (Med J Indones 2009; 18: 53-9)

Kata kunci penalaran klinik, pengetahuan dasar, berpikir kritis, kurikulum berbasis kompetensi

\begin{abstract}
Aim Clinical reasoning is one of the essential competencies for medical practitioners, so that it must be exercised by medical students. Studies on quantitative evidence of factors influencing clinical reasoning ability of students are limited. The aim of this study was to determine the influence of knowledge and other factors on the clinical reasoning ability of the students, which can serve as reference to establish methods for leaming clinical reasoning.
\end{abstract}

Methods This is a cross-sectional study on fourth semester students enrolled in the Competency-based Curriculum of the Medical Faculty, University of Sriwijaya. Data on clinical reasoning ability and risk factors during urogenital block were collected in April 2008, when the students have just completed the block. Clinical reasoning ability was tested using the Script Concordance test and the risk factors were evaluated based on formative tests, block summative assessments, and student characteristics. Data were analyzed by Cox regression.

Results The prevalence of low clinical reasoning ability of the 132 students was $38.6 \%$. The group with low basic knowledge was found to have $63 \%$ risk of low clinical reasoning ability when compared to those with high basic knowledge (adjusted $\mathrm{RR}=1.63 ; 95 \%$ confidence interval $(\mathrm{Cl})=1.10-2.42$ ). When compared to students with high critical thinking skills, those with low critical thinking skills had 2.3 time to be low clinical reasoning ability (adjusted $\mathrm{RR}=2.30 ; 95 \% \mathrm{CI}=1.55-3.41$ ).

Conclusion Students with low critical thinking skills or with inadequate knowledge had a higher risk of low clinical reasoning ability. (Med J Indones 2009; 18: 53-9)

Keywords clinical reasoning, basic knowledge, critical thinking, competency-based curriculum 
The medical practitioners is expected to provide high quality health services. There are 44,000 to 98,000 American that died each year due to preventable medical errors.' Studies on malpractice cases in the United States showed the most frequent source of these failures to diagnose are the physicians themselves. The failures stem from the limited competency of the clinicians. These include faulty decisions, insensitivity to patient data, and inadequate knowledge of patient problems. ${ }^{2}$

Sibert et al stated that clinical competencies should include clinical and interpersonal skills in interacting with the patient, having sound basic knowledge, in addition to problem-solving and clinical reasoning abilities. Of all these, clinical reasoning is the most important component of clinical competency. ${ }^{3}$ Clinical reasoning is a cognitive process through which clinical cases are synthesized and integrated with knowledge and experience to diagnose and manage the patient's problem. ${ }^{4}$

Clinical reasoning is a skill that can be developed through a leaming process. ${ }^{5}$ Proficiency can also be assessed and one of the instruments used is the Script Concordance (SC) test. This test has been shown to be able to demonstrate the reasoning process. It is also easy to construct and organize, furthermore it can be standardized and directly evaluated objectively and quantitatively. ${ }^{6}$

As an institution responsible for producing medical doctors, the medical faculty is obligated to build clinical reasoning ability in the students though various learning methods. In order to choose the appropriate learning methods, factors that influence clinical reasoning must first be determined. Prior to this, factors have only been approached qualitatively. The aim of this study was to determine the factors that influence clinical reasoning ability of the students in a Competency-based Curriculum (CBC) of the University of Sriwijaya (UnSri) Faculty of Medicine through a more quantitative approach.

\section{METHODS}

A comparative cross-sectional study was undertaken on 135 medical students in a Competency-based Curriculum (CBC) of the University of Sriwijaya (UnSri) in April 2008. Subject was excluded from this study if he or she did not complete the entire process. Relevant clinical reasoning ability associated with urogenital cases was selected. Students of semester IV of the CBC program entered the urogenital and body fluids block (Block XI) from the end of February until mid April 2008.

Clinical reasoning ability was assessed by script concordance test. Other influencing factors such as basic medical knowledge, clinical skills, communication skills, critical thinking skills, grade point average, gender and mode of entrance were assessed by some formative assessments, summative assessments and questionnaires.

\section{Constructing and Scoring the Script Concordance (SC) Test}

The Script Concordance (SC) test is a written test. The teaching staff of the Division of Kidney Diseases and Hypertension of the Internal Medicine Department of UnSri Medical Faculty was invited to participate in constructing the test. This group determined clinical cases to be tested by referring to the competency objectives of the block. The cases include nephritic syndrome, nephrotic syndrome, renal failure, and urinary tract infection. These four cases were presented as vignettes. After cases were constructed, lists of questions were prepared based on diagnostic hypothesis, investigative actions, and patient management options. The complete SC test comprised of 60 items (Table 1). The subject was asked to take the SC test. Each student carried out the test individually for 60 minutes.

The scoring process was derived from the aggregate scoring method. There were no wrong or right answers. The subject's answers were compared to answers given by the experts/specialists in the respective field.? After the format was constructed, nine consultant internists were asked to be the panel of experts. Answers given by this panel became the reference for scoring the subject's answers. For example, if an item was chosen by 6 out of 9 panel members, and the subject also chose the same item as the 6 members, then the subject will receive a score of 0.67 , and so on for the rest of the questions.

When the test was tried out on the panel of experts, they chose diverse answers to the 60 test questions. However, even though the answers were diverse, they showed a tendency to agree on certain answers. If a subject was able to choose the same answers on all 60 questions on the Likert scale consistent to the answers chosen by the majority of the reference panel, the subject received a maximal score of 31.89 . This score is designated as $100 \%$. For instance, if a subject receives a score of 20 , 
Table 1. Script Concordance Test sample questionnaire

\begin{tabular}{|c|c|c|c|c|c|}
\hline Diagnostic Hypothesis & $\begin{array}{l}\text { Ruled out or } \\
\text { almost ruled } \\
\text { out }\end{array}$ & Less probable & $\begin{array}{l}\text { Neither less } \\
\text { nor more } \\
\text { probable }\end{array}$ & $\begin{array}{c}\text { More } \\
\text { probable }\end{array}$ & $\begin{array}{l}\text { Certain } \\
\text { or almost } \\
\text { certain }\end{array}$ \\
\hline $\begin{array}{l}\text { If you find Mr. Su'eb suffered from } \\
\text { nephritic syndrome, proteinuria, then you } \\
\text { think }\end{array}$ & * & * & * & * & * \\
\hline $\begin{array}{l}\text { If you find Mr. Su'eb with urinary bladder } \\
\text { calculi, edema of the eyelids in the } \\
\text { moming, then your assumption will be }\end{array}$ & * & * & * & $*$ & * \\
\hline $\begin{array}{l}\text { If you find Mr. Su'eb suffered from tumor } \\
\text { of the urinary bladder, raised plasma } \\
\text { concentration of urea and creatinine, then } \\
\text { your assumption becomes }\end{array}$ & * & * & * & * & * \\
\hline
\end{tabular}

then his percentage is $62.72 \%$ of the maximal score, or just written down as 62.7. Students' score were divided into 2 categories low and high ability of clinical reasoning with cut-off point $55 \%$. The percentage was chosen based on holistic standard cause there is no standard reference. ${ }^{8}$

\section{Assessment of Other Influencing Factors}

The level of basic knowledge was assessed from Multiple Choice Question (MCQ) summative test in the urogenital and body fluids block. Basic knowledge was divided into 2 categories low and high basic knowledge with cut off point 45 , based on agreement by experts. The experts determined pass or fail border using Angoff's standard setting reference. ${ }^{8}$ Data on clinical skills were the grades received by the subject during Objective Structured Clinical Examination (OSCE) of the urogential and body fluids block, and the categories to determined low and high skill were 65 , based on holistic standard given by experts.

Data on communication skills and critical thinking skills were based on average score of tutor evaluation sheets on the subject's ability to communicate during 8 sessions of tutorial discussion. The components evaluated in communication skills were the ability to ask questions, put forth argumentations, or formulate ideas clearly and concisely. Whereas, components of critical thinking skills include the ability to pose questions and give explanatory statements, to argue logically and supply information based references using their own words. ${ }^{9}$ The score for both components were: $1=$ never, $2=$ rarely, $3=$ occasionally, $4=$ frequently, $5=$ always. Communication and critical thinking skills were divided in to 2 categories high and low skills with score 3 as holistic approach cut off point. ${ }^{8}$

Data on Grade Point Average (GPA) were secondary data taken from grades achieved in prior blocks (I-X). Subject with GPA lower 3.0 would be categorized low GPA while other higher GPA. Data on student characteristics were taken from questionnaires given to the students. The questions were on gender and the mode of entrance to the university.

\section{Assuring of Data Quality}

Steps were taken to insure the quality of the data obtained. After construction, the SC test was given to 2 internists, consultant specialists in Kidney Diseases and Hypertension, who were asked to analyze each test item. Before given to the subject, the SC test was first given to a panel of experts. The results from the reference panel were analyzed psychometrically with Cronbach's alpha coefficient through the SPSS program. Questions with low validity and reliability were discarded or rewritten. A hundred and twenty questions were created and given to the reference panel to be answered. From 120 questions, 60 questions with the highest reliability were selected. The minimum alpha reliability coefficient for the test was $0.7 .{ }^{10}$ After being reviewed by the nine experts of the reference panel, the alpha coefficient for 120 questions became 0.679 . 
From this, 60 questions with the highest reliability were again selected. Reliability coefficient for the 60 questions was 0.911 .

To ensure the degree of validity, the 2 internists specializing in Kidney Diseases and Hypertension were once again asked to review the selected 60 questions. The SC test was also given to 36 residents in internal medicine. Clinical reasoning increased proportionate to increased knowledge and experience. ${ }^{11}$ The average test results for the residents was higher than the subjects $(65.14 \pm 5.9$ vs. $56.08 \pm 6.93)$. Independent $\mathrm{T}$ test showed a significant difference between the two groups $(\mathrm{p}<0,000)$.

Attempts were made to clarify any uncertainties in the various factors that influenced clinical reasoning. For example, the MCQ and OSCE examinations were compared to the block's learning objectives. For critical thinking and communication skills, the tutors were given guidelines on evaluation. If there are any doubts, the tutors were asked to clarify the evaluation immediately after a tutorial session.

\section{Data Analysis and Ethics Approval}

The dependent variable in this study is the clinical reasoning ability in diseases of the urogenital system. Independent variables include knowledge, clinical skills, communication skills, GPS, gender, and mode of entrance to the university. All of the data were adjusted to ordinal scale. Data were processed by computer using STATA Release 10.0. Relative risk was calculated to identify risk factors for low clinical reasoning ability, and analyzed by Cox regression. The analysis was chosen because of low prevalence of low clinical reasoning ability $(38.6 \%) .^{12}$

This observational study was approved by the Research Ethical Committee of the University of Indonesia Faculty of Medicine. Written as well as oral information on the study were given to all subjects prior to data collection. The subject then signed an informed consent form.

\section{RESULTS}

One hundred and thirty five students participated in this study. Three students were excluded from further analysis because of absence. Clinical reasoning was evaluated using the Script, Concordance Test. The results showed $38.6 \%$ students had low clinical reasoning ability.
From table 2 it can be seen that the clinical reasoning was equally distributed in terms of risk factors such as GPA, gender, and mode of entrance, as well as communication skills.

Table 2. Some characteristics of students and the risk of low clinical reasoning ability in urogenital disorders

\begin{tabular}{|c|c|c|c|c|c|}
\hline & \multicolumn{2}{|c|}{$\begin{array}{l}\text { Clinical } \\
\text { reasoning ability }\end{array}$} & \multirow{2}{*}{$\begin{array}{l}\text { Crude } \\
\text { relative } \\
\text { risk }\end{array}$} & \multirow{2}{*}{$\begin{array}{c}95 \% \\
\text { confidence } \\
\text { interval }\end{array}$} & \multirow[t]{2}{*}{$\mathrm{P}$} \\
\hline & $\begin{array}{l}\text { High } \\
(\mathrm{n}=8 \mathrm{I})\end{array}$ & $\begin{array}{c}\text { Low } \\
(\mathrm{n}=51)\end{array}$ & & & \\
\hline \multicolumn{6}{|l|}{$\begin{array}{l}\text { Grade point } \\
\text { average }\end{array}$} \\
\hline High & 42 & 24 & 1.00 & Reference & \\
\hline Low & 39 & 27 & 1.13 & $0.65-1.95$ & 0.675 \\
\hline \multicolumn{6}{|l|}{ Gender } \\
\hline Male & 23 & 19 & 1.00 & Reference & \\
\hline Female & 58 & 32 & 0.79 & $0.45-1.39$ & 0.406 \\
\hline \multicolumn{6}{|c|}{ Mode of entrance } \\
\hline SPMB * & 52 & 36 & 1.00 & Reference & \\
\hline Special path & 29 & 15 & 0.83 & $0.46-1.52$ & 0.553 \\
\hline \multicolumn{6}{|c|}{ Basic Knowledge } \\
\hline High & 64 & 29 & 1.00 & Reference & \\
\hline Low & 17 & 22 & 1.81 & $1,04-3.15$ & 0.036 \\
\hline \multicolumn{6}{|l|}{ Clinical skills } \\
\hline High & 35 & 15 & 1.00 & Reference & \\
\hline Low & 46 & 36 & 1.46 & $0.80-2.67$ & 0.215 \\
\hline \multicolumn{6}{|c|}{$\begin{array}{l}\text { Critical thinking } \\
\text { skills }\end{array}$} \\
\hline High & 66 & 25 & 1.00 & Reference & \\
\hline Low & 15 & 26 & 2.31 & $1.33-4.00$ & 0.003 \\
\hline \multicolumn{6}{|l|}{$\begin{array}{l}\text { Communication } \\
\text { skills }\end{array}$} \\
\hline High & 33 & 44 & 1.00 & Reference & \\
\hline Low & 17 & 38 & 0.76 & $0.43-1.36$ & 0.357 \\
\hline
\end{tabular}

*SPMB: [ndonesia acronym for national selection of new student revenue

Out of seven influencing factors for clinical reasoning ability, Cox regression analysis resulted only 3 variables showed significant crude relative risk, i.e. basic knowledge, critical thinking skills and clinical skills. All of them were then analyzed in final model. In the final model (table 3), basic knowledge and critical thinking skills were the dominant factors associated with clinical reasoning. Students that were not skilled in critical thinking had a 2.3-fold risk of low clinical reasoning compared to those skilled in critical thinking. When observed from the aspect of knowledge, students with low basic knowledge had a $63 \%$ risk of low clinical reasoning ability compared with students with high basic knowledge. 
Table 3. The relationship between knowledge, critical thinking skills, and clinical skills on the risk of low clinical reasoning ability in urogenital disorders

\begin{tabular}{|c|c|c|c|c|c|}
\hline & \multicolumn{2}{|c|}{$\begin{array}{c}\text { Clinical } \\
\text { reasoning ability }\end{array}$} & \multirow{2}{*}{$\begin{array}{l}\text { Adjusted } \\
\text { relative } \\
\text { risk* }\end{array}$} & \multirow[t]{2}{*}{$\begin{array}{l}\text { Confidence } \\
\text { Interval } 95 \%\end{array}$} & \multirow[t]{2}{*}{$P$} \\
\hline & $\begin{array}{l}\text { High } \\
(\mathrm{n}=81)\end{array}$ & $\begin{array}{c}\text { Low } \\
(\mathrm{n}=51)\end{array}$ & & & \\
\hline \multicolumn{6}{|c|}{ Knowledge } \\
\hline High & 64 & 29 & 1,00 & Referrence & \\
\hline Low & 17 & 22 & 1,63 & $1,10-2,42$ & 0,014 \\
\hline \multicolumn{6}{|c|}{$\begin{array}{l}\text { Critical } \\
\text { thinking } \\
\text { skills }\end{array}$} \\
\hline High & 66 & 25 & 1,00 & Reference & \\
\hline Low & 15 & 26 & 2,30 & $1,55-3,41$ & 0,003 \\
\hline \multicolumn{6}{|c|}{ Clinical skills } \\
\hline High & 35 & 15 & 1,00 & Reference & \\
\hline Low & 46 & 36 & 1,35 & $0,84-2,17$ & 0,208 \\
\hline
\end{tabular}

* Relative risk is adjusted between the variables in this table

\section{DISCUSSIONS}

This study has several limitations. One limitation was the number of sample analyzed for risk factors in clinical reasoning ability. It consisted of only $132 \mathrm{CBC}$ students out of more than 1000 medical students at UnSri. Each class will of course have different characteristics.

A few instruments for evaluating the risk factors, such as communication skills and critical thinking skills were based on tutor evaluation that can be subjective. The tutors must also evaluate 10-12 students simultaneously, and may be unable to obtain a complete or accurate assessment. To minimize information bias, the tutors were thoroughly provided with strict guidelines for assessing the students. At the end of every tutorial session, the tutors were asked to clarify any uncertain data on evaluation.

This study did not analyze other risk factors that may influence clinical reasoning ability, such as the level of intelligence, clinical experience, and prior learning experiences. Clinical reasoning is an intellectual process that needs cognitive skills. ${ }^{13}$ Therefore, the level of intelligence will influence this reasoning process. After analyzing clinical reasoning using $\mathrm{SC}$ test, Charlin et al concluded that clinical experience significantly influence clinical reasoning. ${ }^{14}$ Komputsa et al also showed that experienced clinicians exhibited better clinical reasoning than newly graduated clinicians. ${ }^{15}$
The level of intelligence was not evaluated in this study because the students accepted to UnSri Medical Faculty are students that have underwent a rigorous selection process. Clinical and learning experiences were also not assessed because the students have had only minimal exposure to clinical experience in the subject of urogenital system.

The results of this study showed that if 55 was the passing grade for good clinical reasoning, then $38.6 \%$ of the students had low clinical reasoning ability. This condition is probably due to the student's learning processes and other factors that did not optimally enhanced clinical reasoning skills.

The students taking the SC test were students at the beginning of their medical education (semester IV) where knowledge and clinical experience were just forming. The learning experience integrated all branches of medical science on the urogenital system for 6 weeks with tutorial discussions for only 4 cases. These cases were not the exact match of the cases in the SC test.

The study was focused on lower rate of clinical reasoning ability. Clinical reasoning is the most important competency for doctors, that must be systematically developed earlier. ${ }^{3}$ Lower ability of clinical reasoning will affect performance of medical competencies.

The failure rate of these students was lower than the results of the final semester medical students in France taking the web-based SC test in urology. It was reported that failure in the French students was $80 \%{ }^{3}$ But simple comparisons cannot be made since learning experiences, level of difficulty of the SC test, and the passing grades between the 2 groups were probably not the same.

Gender was not found to influence clinical reasoning. Literature actually mention that female students tended to show better academic and clinical performances compared to male students. This was probably due to female students being more sensitive with more attention to detail when evaluating the patient. This difference may be significant if the sample was greater. ${ }^{16}$

Grade Point Average (GPA) did not influence clinical reasoning ability. Ferguson, James, and Madeley reported that the student academic performance had only a small influence on the student's competence as a doctor. They found that many factors, such as cognitive factors (prior academic ability, entrance mode), noncognitive factors (personality, method of studying, 
and the student's facilities), the learning process, and demographic factors, influenced academic performance more. These factors may be better associated with GPA than with clinical reasoning. ${ }^{16}$ Besides, GPA is the result of summative evaluation that could be influenced other factors such as validity and reliability of the test questions. ${ }^{8}$ Mode of entrance also did not influence clinical reasoning ability. All of students were selected in some strict criteria. In all direction of mode of entrance, they were best candidate

Communication skills were not found to influence clinical reasoning ability in the students. This study assessed communication skills through tutor observation during group discussions. The observed communication skills were oral communication skills, which is the ability to express information or ideas concisely and clearly. Communication skills are actually one of the important components of medical competence. However, in association to clinical reasoning, communication skills are better suited to probe information/data from the patient, educate the patient, and interdisciplinary interaction with other professionals. On the other hand, clinical reasoning is a cognitive process that needs the ability to organize data and knowledge critically based on former experience..$^{5.17}$

The results of this study showed that clinical reasoning is influenced by knowledge and critical thinking skills. Clinical reasoning is a cognitive process where various information from the clinical case is synthesized and integrated with knowledge and experience, and then applied to clinical decisions such as formulating a diagnosis and choosing the correct patient management. ${ }^{5,17}$

Clinical reasoning is build up by collecting a range of basic knowledge and the development of critical thinking skills. ${ }^{18}$ Every doctor and medical student need critical analytical skills, which are logical and based on strong knowledge as part of their clinical competence. ${ }^{5}$ The first step of clinical reasoning process is collecting, organizing and interpretation of data. For the reason, the doctor must identify the problem and critically analyzes it to make some priorities. On the next step, students must generate the hypothesis and critically analyze it to make the diagnosis. The hypothesis will be critically evaluated and compared with some alternatives diagnosis. On the last step, doctor must determine some alternative investigations and management strategies. He also has to think critically to choose the most apropiate investigation and management strategies for each patient. ${ }^{13}$
Clinical skills assessed by OSCE tend to moderately influence clinical reasoning ability of the students. The OSCE is a tool for assessing the performance of clinical skills that is also associated with knowledge and reasoning, but in OSCE, the skill itself is a more dominant aspect than cognitive aspect. Smee stated that skill assessment is not interchangeable with test that assess knowledge and reasoning. ${ }^{19}$ Boursicott and Robert have also stated that OSCE cannot assess every component of competency, since some clinical skills are not based on knowledge and reasoning. ${ }^{20}$

Clinical reasoning can be strengthened by developing knowledge and critical thinking skills through a suitable learning concept. Experts suggested applying constructivism learning concept to build all 3 components. Constructivism is focused on preparing the students to solve problems in uncertain/ambiguous situations. Through the concept of constructivism, the students can construct reality based on the perception of their experience. ${ }^{21}$

The essence of constructivism is reflection and feedback in all aspects of the learning process. Experience obtained through that learning process has to be discussed reflectively (reflective discourse) and through this reflective discourse a critical reflective process will occur. ${ }^{22}$ This reflection makes it possible for the student to rebuild and rearrange concepts, skills, knowledge, as well as values into the fabric of their existing knowledge. ${ }^{23}$

The constructive learning concept, emphasizing the concept of reflective discourse and feedback, can be achieved through several methods. The concept can be accomplished though reflective discourses where all the participants will stand equally. ${ }^{23}$ Other methods of learning include peer tutoring, collaborative learning, and self directed learning. ${ }^{16,22}$

In conclusion, this study showed that a low level of knowledge and low level of critical thinking ability influenced clinical reasoning ability. Therefore, more effective and efficient learning efforts are needed to improve poor clinical skills, such as by improving basic knowledge and critical thinking skills by the students. The process of learning and building basic knowledge and critical thinking skills can be achieved through constructivism learning concepts that emphasize the reflective process and feedback. 


\section{Acknowledgements}

The author wishes to thank all the year 2006 students of the CBC program of University of Sriwijaya, Medical Faculty for their willing participation in this study. The author also wishes to thank the faculty executives, education unit, and administrative staff of the University of Sriwijaya Medical Faculty that have given permission as well as assistance in the data collecting, and especially to Prof. Bastaman Basuki, Dr. Abdul Latief SpA (K), and Dr. Minarma Siagian for their invaluable technical assistance in this study.

\section{REFERENCES}

1. Public Citizen's Conggress Watch. Medical misdiagnosis. Challenging the malpractice claims of the doctors' lobby. 2003 [cited 2008 Des 10]. Available from: www.tradewatch. org/documents/PDF\%20of20Report.pdf

2. Becker JF. Failure to diagnose. [cited 2008 April 20]. Available from: http//:pittburgh/misdiagnosis lawyer/ becker.htm.

3. Sibert L, Darmoni SJ, Dahamna B, Weber J, Charlin B. On line clinical reasoning assessment with the script concordance test: a feasibility study. BMC Medical Informatics and Decision Making [home page on internet]. 2005 [cited 2008 Mar 03];5:1-10. Available from: http:// www.biomedcentral.com/1472-6947/5/18.

4. Groves M, Scott I, Alexander H. Assessing clìnical reasoning: a method to monitor its development in a $\mathrm{PBL}$ curriculum. Med Teach. 2002;24:507-15.

5. The College Faculty; University of Washington, School of Medicine. The clinical reasoning guidelines for "ICM II". Washington DC: The College; 2005.

6. Sibert L, Darmoni SJ, Dahamna B, Hellot F, Weber J, Charlin B. On line clinical reasoning assessment with script concordance test in urology: result of a French pilot study. BMC Med Educ [homepage on internet]. 2006 [cited 2008 Mar 06];6:1-12. Available from: http://www.biomedcentral. com/1472-6920/6/45

7. Charlin B, Roy L, Brailovsky C, Goulet F. The script concordance test: a tool to assess the reflective clinician. Teaching and Learning in Medicine. 2000; I2:189-95.

8. Searle J. Defining competency-the role of standard setting. Med Educ. 2000;34:363-6
9. Si-Mui S, Azila NMA, Lay-Hoong L, Tan CP, Nget-Hong T. A simple instrument for the assessment of student performance in problem-based learning tutorial. Ann Acad Med Singapore. 2006;35:634-41.

10. What does Cronbach's alpha mean? UCLA Academy Technology Services. [serial online]. 2007. [cited 2008 Mar 14]. Available from: http://www.ats.ucla.edu/stt/spss/ faq/alpha.html.

11. Norman G. Research in clinical reasoning: past history and current trends. Med Educ. 2005;39:418-27.

12. Вarros AJD, Hirakata VN. Alternative for logistic regression in cross-sectional studies: an empirical comparison that directly estimates the prevalence ratio. BMC Medical Research Methodolody [serial online]. [cited 2006 Agustus 01 ]; 3 (21):[13p] Available from: http://www.biomedcentral. com/1471-2288/3/21.

13. Jenicek M. A physician's self-paced guide to critical thinking. American Medical Association; 2006

14. Charlin B, Gagnon R, Pelletier J, Coleti M, Abi-Rizk $\mathrm{G}$, Nasr C, et al. Assessment of clinical reasoning in the context of uncertainty: the effect of variability within the reference panel. Med Educ. 2006;40:848-54.

15. Khonputsa P, Besinque K, Fisher D, Gong WC. Use of script concordance test to assess pharmaceutical diabetic care: a pilot study in Thailand. (abstract). Med Teach. 2006;28:570-3.

16. Ferguson E, James D, Madeley L. Factors associated with success in medical school: systematic review of the literature. BMJ. 2002;324:952-7.

17. Suebnukam S, Haddawy P. Clinical reasoning skill acquisition through intelligent group tutoring. Asian Institute of Technology Computer Science and Information Management Program [serial online]. 2005 [cited $2008 \mathrm{Mar}$ 06]; Available from: http://ait.ac.th.

18. Pithers RT, Soden R. Critical thinking in education: a review. Educational Research. 2000;42:327-49.

19. Smee $\mathrm{S} . \mathrm{ABC}$ of leaming and teaching in medicine: skill based assessment. BMJ. 2003;326:703-6.

20. Boursicot K, Roberts T. How to set up an OSCE. The Clinical Teacher. 2005;2:16-20.

21. Mergel B. Instructional design and leaming theory. 1998 [cited 2007 Sept 14]; Available from: file:///G:/Learning\%20 Theories\%20of\%20 Instructional \%20 Design.htm.

22. Merriam SB. The role of cognitive development in Mezirow's transformational learning theory. Adult Education Quarterly. 2005;55:60-8.

23. Branch WT, Paranjape A. Feedback and reflection: Teaching methods for clinical settings. Academic Medicine. 2002;77:1185-6. 